\title{
Integrating Game-based Interactive Media as Instructional Media: Students' Response
}

\author{
Dwi Yuniasih Saputri ${ }^{1}$, Rukayah $^{2}$, Mintasih Indriayu $^{3}$ \\ ${ }^{1,2}$ Department of Elementary School Teacher Education, Sebelas Maret University, Indonesia \\ ${ }^{3}$ Department of Economy Education, Sebelas Maret University, Indonesia
}

\section{Article Info \\ Article history: \\ Received Dec 12, 2017 \\ Revised Jan 25, 2018 \\ Accepted Aug 27, 2018}

Keywords:

Elementary School

Game

Instructional Media

Interactive multimedia

Students Response

\begin{abstract}
Instructional media functioning to deliver the lesson has a very important role. There are a lot of instructional media used in learning process; one of those is interactive multimedia. This study aims to find out students response toward game based interactive media as instructional media in elementary school. The method used in this study was descriptive qualitative. The sample in this study was 10 students $5^{\text {th }}$ grade elementary school. The data collecting methods were interview, observation and questionnaire. The collected data were analyzed by using interactive analysis consist of data collecting, data reduction, data presenting and conclusion. The result of this study shows that the student gave a good response toward game-based interactive multimedia. The students like and support the use of game based interactive multimedia as instructional media. Students felt that it was easier to understand lesson because the lesson was delivered not only through text, but also picture, audio, video and animation. The game in interactive media make the student be entertained and active in learning process. It is suggested that the teacher cooperate with the expert in education technology to improve interactive multimedia as interaction media.
\end{abstract}

Copyright (C) 2018 Institute of Advanced Engineering and Science. All rights reserved.

Corresponding Author:

Dwi Yuniasih Saputri,

Departement of Elementary School Teacher Education,

Sebelas Maret University,

36A Ir. Sutami Road, Surakarta, Jawa Tengah, Indonesia.

Email: dwiyuniasih@student.uns.ac.id.

\section{INTRODUCTION}

The success of learning process is related instructional media. Instructional media is a part of communication process which can affect the quality of comunication in learning. Instructional media is used as supporting tool used in leaning process to improve the effectiveness and efficiency in achieving learning objective. Effective and efficient learning process is characterized by the students as the receiver of lesson can receive the lesson delivered by the teacher so that the learning process can run well.

Instructional media used at school has various types. Common instructional media used is classified onto several category, those are: text media, audio media, visual media, video media, engineer and people. Instructional media is not only in a form of physical goods, but all supporting learning process including people is also instructional media. Based on its type, instructional media is classified into four category, those are visual media, audio media, audio-visual media and multimedia [1].

One of media instructional media type used at school is multimedia. Multimedia means, combination of text, audio, still images, animation, video and interactivity content forms delivered electronically" [2]. Multimedia is categorized into two; those are linear multimedia and interactive multimedia. The difference of both media is that linear multimedia not equipped with controlling tools, meanwhile interactive media has controlling tools which can be operated by users so that they can choose for further process [3]. 
Learning process using interactive multimedia able to activate student to study with high motivation because their interest toward multimedia which can provide text, picture, video, audio and animation [4]. The combination of text, picture, video, audio and animation can be the effective source for students. The more senses used in accepting information and processing, the more the information would be accepted and long lasting in memory [5].

Interactive multimedia is not only ease the student to study but also aim to give the facility various learning method. Students have different learning method, some are faster learning through visual media, some others are audio media, print media, and audio-visual media and so on [6]. Interactive multimedia becomes a solution to overcome different student learning styles. In addition students are now born in an environment equipped with advanced technology. Therefore, the way to teach indigenous digital needs to be changed by integrating technology in learning so that it fits students' interests [7].

Based on interview with elementary school, there are only few teachers use instructional media. Students' motivation is low. This phenomenon gives impact to students' study evaluation become low. The low use of instructional media is caused by time limitation to deliver abundant material. Furthermore, teacher has a lot of duty related to school administration so that they rarely have time to prepare lesson plan using instructional media involving computer technology. Interview resul is in accordance with the study which showed that "few teachers used computers for teaching and learning purposes while majority of them used computers for administrative purposes. Additionally, teachers were found to have limited confidence in using technology to facilitate specific concepts or skills, to support creativity, and to support students to learn complex concepts" [8].

Since new curriculum was applied, the subject of information and communication technology (TIK) is used as learning facility. subject of information and communication technology (TIK) become instructional media of other subject. Based on the result of interview, the use of computer laboratory is not maximum, because it is only used for intraculicular subject. This phenomenon is in accordance with the result of study which show that "Although rapid advances in technology has allowed for the growth of collaborative elearning experiences unconstrained by time and space, technology has not been heavily infused in the activities of teaching and learning" [9].

There are a lot of study results about positive impact os interactive multimedia in learning process. The result of study of multimedia development in learning of Information and Communication Technology (TIK) based on self learning show that instructional media shows that the instructional media can give stimulation toward child's independency, creativity and self control, consistence and good commitment toward themselves [10]. Other study which has develop interactive multimedia by integrating life value with learning material is proven to increase students' character [11]. There is a study result which has develop multimedia application proven to help teenager in increasing knowledge and awareness about cyber bullying [12]. Moreover there is study result which stated that the use of flash-based animation book as media can increase students motivation [13]. Based on several studies done by expert, it can be conclude that interactive multimedia has important role in learning process. The use of interactive multimedia gives space for student to be more active in learning. Interactive social media was laso affect student interest and students' achievement.

The difference of this study from previous studies is that this study focuses on students response when the teacher integrates game-based interactive social media as instructional media. Current interactive multimedia in school is commonly in the form of tutorial and rarely integrates it to game. The integration of game in interactive multimedia is expected can give positive response of student toward lesson and learning process. Those responses are related to current students characteristic. Student in recent era is habituated to sophisticated digital gadget. This study aims to find out students' response toward game-based interactive multimedia as instructional media. The finding of this study is expected to be the reference for other researcher to develop innovative interactive multimedia to be implemented in elementary school.

\section{RESEARCH METHOD}

This research type is descriptive study using qualitative approach. The locations of this research are at 4 elementary schools in Surakarta city, those are SD Warga, SD Muhammadiyah 1 Surakarta, SD AlAzhar Syifa Budi and SD Al-Abidin. This study was conducted in July-October 2017. The procedures were interviews with teachers related to commonly used instructional media, making research instruments in the form of interview guides, observation page and questionnaires. The data source in this study was the subject of research consisting of teachers and students, as well as events related to the research. Data collection methods in this study are interviews, observations and questionnaires. Questionnaires are used to support the collection of main data. Measurement of data validity is done through triangulation method. The data 
obtained were analyzed using interactive analysis techniques consisting of: data collection, data condensation, display data, and conclusion [14].

\section{RESULTS AND ANALYSIS}

\subsection{Study Result}

Based on the results of interviews most students stated that they were happy and support the use of games-based interactive multimedia as instructional media. As stated by informant 1 that "I am happy to use the instructional media because it is fun games". The informant also revealed "I can learn while playing so I do not get dizzy because I am entertained with the game in the instructional media". Another opinion was also expressed by informant 5 that "I want to learn to use instructional media like games more often because there are images and videos so learning becomes easier". Informant 6 reveals that "I prefer learning using instructional media because there are games that make me think and I would be serious in reading the material in order to complete the game". Informant 7 explains that "I am more interested in learning to use a computer than learning to use textbooks just because I do not get bored quickly". Informant 9 gives the opinion that "I am so eager to learn because the thematic learning is done using computer in the laboratory room. Usually I use computer only for learning technology, information and communication only ".

Based on observations of using games-based interactive multimedia, students listen to the material seriously. Students pay attention to the material and focus on each computer. Students learn on their own without asking for help from friends, but there are some students who sometimes ask for guidance from the teacher. Most students follow the game plane seriously. Games contained in interactive multimedia are an adventure game that begins with problems that must be solved by the students. To solve the problem the students have to read the material then complete the challenge on each sub-section of the material. Students read the material seriously. After that, the students do the game at the end of the sub-chapter. The game is like filling in questions, puzzles, composing or moving answers, and matching quizzes. Some even laugh with excitement for getting positive feedback because it can solve the challenge well. There are also students who are disappointed because they cannot solve the challenge, and then they read carefully the next material in order to solve the challenge. Examples of games contained in interactive multimedia can be seen in the following figure.

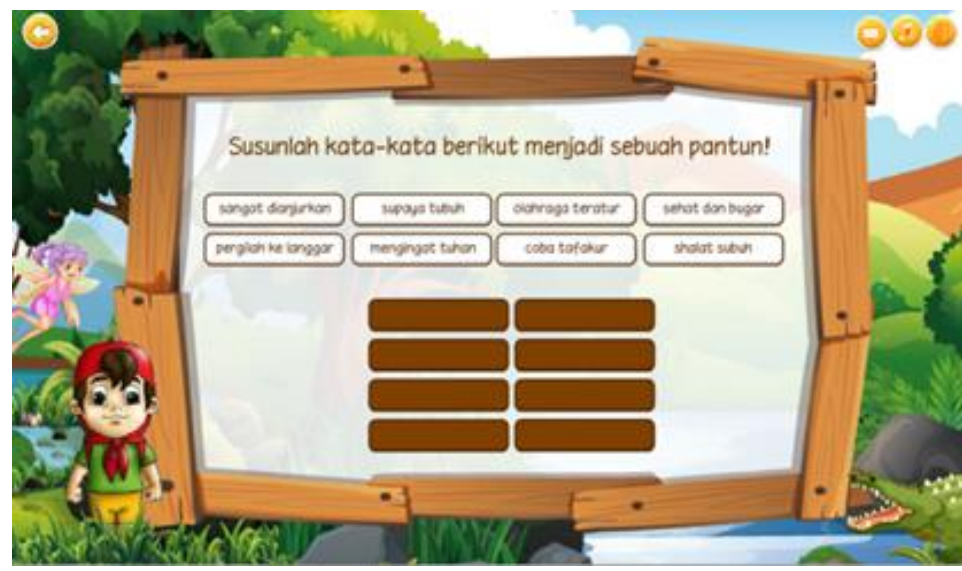

Figure 1. Games in interactive multimedia

Students' responses to interactive multimedia can also be known through questionnaires given to students after using game-based interactive multimedia. Researchers use questionnaires to support data obtained from interviews and observations. Questionnaires are divided into several aspects, those are display aspects, technical aspects, material aspects and learning aspects.

Display aspects consist of the accuracy of the media in terms of layout, text, images, video, animation and audio. Response to the aspect of the display included in the good category. This is indicated by student answers by providing comments about the layout, text, images, video, animation, and audio is in accordance with the material and easy to understand. Students more easily understand the material presented because there are images, audio, and video that can clarify the material. Based on students' opinion, the display of game-based interactive multimedia make them be motivated in learning. Students become 
encouraged to learn because the material is displayed interestingly. However, there are student comments about the text in game-based interactive multimedia that the font as too small so it needs to be fixed.

Technical aspects consist of ease in operating the media and ease of navigation. Based on the results of the questionnaire from the technical aspects it shows that game-based interactive multimedia are easy to use and the navigation is easy to understand. Students are accustomed to using the applications in the computer or mobile phone so that it was not difficult to use interactive multimedia. Based on student testimony, the buttons in game-based interactive multimedia is simple and has been accompanied by clear instructions so that students were not confused to use interactive multimedia. In addition, the interactivity makes students passionate in learning as there is feedback from interactive multimedia-based games.

Material aspects consist of material ease, material clarity, material demands, and clarity about evaluation. Students commented that the material contained in game-based interactive multimedia is clear and coherent. The sequence of the material is appropriate which is starting from the simple to the complicated. In addition, each material is accompanied by real examples so that students become more understanding. Students like the display of evaluation questions because there is feedback on their answers. In addition, the evaluation also displays the value when students have finished working on the problem so that students can find out their ability in understanding the material.

The learning aspect consists of the role of the media in increasing the interest of learning and helping the learning process. Based on the results of the questionnaire, students are helped in learning when using game-based interactive multimedia as a instructional media. It is because the material is not only presented in the form of text, but also pictures and video so that it was easier for student in learning material. Based on student testimony, the use of game-based interactive multimedia increase interest in learning. Students become more motivated in learning as they use game-based interactive multimedia.

\subsection{Discussion}

In general, the subject supports and gives a good response to game-based interactive multimedia. Students feel happy if teachers use interactive multimedia-based games as a instructional media. The findings support the results of research proving that the integration and implementation of computer games into the classroom can help students study more fun and effectively [15]. Students enjoy learning to use technology because they see technology as exciting and entertaining [16]. Being entertained by the game's flow of exciting and exciting adventures. It is in accordance with the results of research that gives the result that game design can attract students' interest and become an effective learning medium used [17]. Interest in instructional media can be seen from students' enthusiasm in listening to material in the form of text, pictures, and videos and in working on the problem. Student attention also becomes focus on computer.

The use of instructional media also affects the increase in student motivation in learning. This is in accordance with the results of study that shows that the computer-aided game as a instructional media can increase student motivation [18]. Learning process which integrate interactive multimedia also increase the interest and spirit of students in learning. It is in accordance with the results of study that shows that multimedia can motivate students with student-centered learning [19]. The game in interactive multimedia makes students motivated in solving challenges. Students who have not succeeded in solving challenges also try not to give up. Students actually become passionate in reading the material and more careful in complete the game to get positive feedback from game -based interactive multimedia. The theory is supported by the results of study that proves that the existence of computer-based educational games to make students happy and enjoy so that students are more motivated and have eagerness to continue learning [20].

Students love the look of the material contained in interactive multimedia because it contains not only text, but there are images, audio, video, and animation. The display of game-based interactive multimedia is more interesting than the usual learning done by using textual book. Students are also easier in understanding the material because the material is concretized with images and videos in game -based interactive multimedia. Based on study results show that students prefer visual aids to get new information and memorize so that it is easier for students to understand the material [21]. The theory is also supported by the results of research proving that the more varied learning media used, the more information received and can improve learning outcomes [22]. The image has more value that can explain the complicated concept that can facilitate students in learning [23]. Interactive multimedia used by students also displays videos related to the material. The material usually presented by using the lecture method is more interesting because it is shown in the form of video. Students at elementary school level is also interested if the presentation of the material by using animation. This is in accordance with the study results that show that the use of animation in interactive multimedia has a positive effect in improving student learning objectives [24]. It is supported more by study results showing that multimedia materials containing video and animation are more appropriate for the visualizer than those that guide text and images only [25]. The use of video and animation can reduce the risk of verbalism because elementary school students are still in concrete operational stages so 
there is a need for visualization to understand the material. Complex material such as natural science and social science is easier to be understood because it is displayed concretely. In addition, the existence of game content also makes it easy for students to memorize the material. The findings are in accordance with the study results that video games can improve cognitive abilities such as the ability to remember in memory [26]. Other studies also provide results that computer-based games can improve student achievement of students' cognitive learning processes [27]. Game content in interactive multimedia is not only useful for giving pleasure to the students but is an effective learning medium used in learning. It is in accordance with study that proves that gaming is not only made for entertainment but also has the potential to improve learning success [28].

Students learn enthusiastically because games-based interactive multimedia stimulate students to be actively involved in learning. Students are actively involved by optimizing the use of the five senses to obtain information contained in interactive multimedia. Based on the observations students enjoy learning and follow the game plot seriously. Interactive multimedia content that contains games and interactivity makes students more active in learning. This is in accordance with the study results that give results that the interactive system facilitates in-depth learning by engaging students actively [29]. The game in interactive multimedia also makes students active in thinking. Students think more actively because trying to solve the challenges in interactive multimedia. Students laugh with joy when they get positive feedback because they have successfully solved the challenge. Students who get negative feedback try to be serious and more careful in solving the challenge. Students are interested and want to continue to try the games contained in interactive multimedia. The game makes students passionate in learning and not easily getting bored.

Integrated interactive multimedia in learning can help teachers in achieving learning objectives. This is because the use of multimedia proven to be effectively to be applied in the world of education so that teachers need to develop multimedia for instructional media [30]. Integration of technology in the classroom is also useful to prepare students in the future [31]. Based on the results of the study, teachers, school administrators, and education stakeholders are recommended to integrate technology in learning process [32].

Based on these findings, teachers need to use games-based interactive multimedia to improve the quality of learning. Games-based interactive multimedia make students learn more interestingly and fun. The display in interactive multimedia consists of text, audio, images, animation, and video also makes students understand more about the material. The presence of games contained in interactive multimedia makes students active in learning the material. So the teachers are recommended to use interactive multimedia-based games for better student response so that learning objectives can be achieved optimally.

\section{CONCLUSION}

The result of interview, observation and questionnaire showed that students give positive response and support the use of game based interactive multimedia. The student would enjoy in learning if the teacher used games-based interactive multimedia as instructional media. This was because the displays in interactive multimedia consist of games which make the student be more interested and motivated in learning. Gamesbased interactive multimedia gave joy to the students so that they were not easily getting bored. The game in interactive multimedia was also make involve actively because the student have to read the material seriously in order to solve the challenge. The students enjoyed the games in interactive multimedia because there was a feedback toward the effort in learning. Interactive multimedia also give the ease to understand the material because it showed not only text but also picture, audio, animation and video which depict the material more understandable. The implication of this study is that the teacher need to use interesting instructional media and in accordance with students characteristic, so that it can give good response toward learning process. So that it can help teacher to achieve learning objective and increase learning process quality.

\section{ACKNOWLEDGEMENTS}

The author send her best gratitude to the principal of SD Warga, SD Muhammadiyah 1 Surakarta, SD Al-Azhar Syifa Budi and SD Al-Abidin, all teachers and students who had participate so that the study could be conducted well.

\section{REFERENCES}

[1] R. Asyhar, "Creative Developing Learning Media”, Jakarta: Referensi Jakarta, 2011, pp. 44-45.

[2] Nachimuthu K. \& Vijayakumari G., "Perceptions on Multimedia technology by College of Education Teachers," Journal of Education and Learning, vol. 6, pp. 167-176, 2012. 
[3] Daryanto, "Learning Media: Its Role Is Very Important in Achieving Learning Objectives (in Bahasa)", Yogyakarta: Gava Media, 2013, pp. 51.

[4] D. Darmawan, "Educational Innovation (in Bahasa)", Bandung: PT Remaja Rosdakarya, 2012, 55-56.

[5] Arsyad, "Instructional Media (in Bahasa)," Jakarta: Raja Grafindo Persada, 2012, pp. 11.

[6] A. S. Sadiman, et. al., "Educational Media, Understanding, Development and Utilization (in Bahasa)," Jakarta: Raja Grafindo Persada, 2012, pp. 10.

[7] J. S. Keengwe \& D. Georgina, "Supporting Digital Natives to Learn Effectively with Technology Tools," International Journal of Information \& Communication Technology Education, vol. 9, pp. 51-59, 2013.

[8] A. Kafyulilo, \& J. S. Keengwe, "Teachers' Perspectives on their use of ICT in Teaching and Learning: A case study," Education \& Information Technologies Journal, vol. 19, pp. 913-923, 2014.

[9] J. S. Keengwe, G. Onchwari \& J. Agamba, "Promoting Effective e-Learning Practices Through the Constructivist Pedagogy," Education \& IT Journal, vol. 19, pp. 887-898, 2014.

[10] S. H. Anwariningsih, \& S. Ernawati, "Development of Interactive Media for ICT Learning at Elementary School Based on Student Self Learning," Journal of Education and Learning, vol.7, pp. 121-128, 2013.

[11] K. Komalasari, Saripudin, \& Didin, "Value-Based Interactive Multimedia Development through Integrated Practice for the Formation of Students' Character," Turkish Online Journal of Educational Technology (TOJET), vol. 16, pp. 179-186, 2017.

[12] N. A Wahab, Wan Ahmad J.W.A \& Balakrishnan M., "The use of Multimedia in Increasing Perceived Knowledge and Awareness of Cyber-Bullying among Adolescents: A Pilot Study," Journal Social and Behavioral Sciences, vol. 176, pp. 745-749, 2015.

[13] Yoon T., "Development of Korean EFL Learnerse Learning Attitude using Flash-Based Animated Books," Journal of Education and Learning, vol. 10, pp. 373-381, 2016.

[14] M. B. Miles \& A. Michael Huberman, "Qualitative Data Analysis (in Bahasa)," Jakarta: UI-Pres, 2009, pp. 14

[15] I. Ahmad \& A. Jaafar, "Computer Games: Implementation into Teaching and Learning," Journal Social and Behavioral Sciences, vol. 59, pp. 515 - 519, 2012.

[16] T. Heafner, "Using Technology to Motivate Students to Learn Social Studies," Contemporary Issues in Technology and Teacher Education (CITE Journal), vol 4, pp. 42-53, 2004.

[17] G. Javidi \& E. Sheybani, "Teaching Computer Programming through Game Design: A Game First Approach," GSTF Journal on Computing (JoC), vol. 4, pp. 17-22, 2014.

[18] H. Park, "Relathionship between Motivation and Student's Activity on Educational Game," International Journal of Grid and Distributed computing, vol. 5, pp. 101-113, 2012.

[19] B. Son, Simonian, \& Mark, "An Integrated Multimedia Learning Model vs. the Traditional Face-to-Face Learning Model: An Examination of College Economics Classes," Journal of Educational Multimedia and Hypermedia, vol. 25, pp. 305-321, 2016.

[20] M. S. Y. Jong etc, "Harnessing Computer Games in Education," Journal of Distance Education Technologies, vol. 6, pp. 1-9, 2008.

[21] Ebata, "Motivation Factors in Language Learning," The Internet TESL Journal, vol 14, 2008.

[22] A. Lutfi, "Motivating Students to Learn Science by Applying Bilingual Comic Learning Media (in Bahasa)," Jurnal Pendidikan dan Pembelajaran, vol 20, pp. 152-159, 2013.

[23] M. I. J. Nazir etc, "Skill development in Multimedia Based Learning Environment in Higher Education: An Operational Model," International Journal of Information and Communication Technology Research, vol. 2, pp. 820-828, 2012.

[24] M. Rusli \& I Komang R. Y. N., "The Effect of Animation in Multimedia Computer-Based Learning and Learning Style to the Learning Results," Turkish Online Journal of Distance Education-TOJDE, vol. 18, pp. 177-190, 2017.

[25] C.-M. Chen \& Y.-C. Sun, "Assessing the Effects of Different Multimedia Materials on Emotions and Learning Performance for Visual and Verbal Style Learners," Computers and Education, vol. 59, pp. 1273-1285, 2012.

[26] M. Adkins, "How Video Games and Digital Literacy Impacts Student Achievement and Development: An Analysis of Synergistic Integration," Proceedings of SITE 2014--Society for Information Technology \& Teacher Education International Conference (pp. 1-5). In Jacksonville, Florida, United States: Association for the Advancement of Computing in Education (AACE), 2014.

[27] T.-Y. Chuang \& W.-F. Chen, "Effect of Computer-Based Video Game on Children: An Experimental Study," Educational Technology \& Society, vol. 12, pp. 1-10, 2009.

[28] L.K. Ahmadi etc, "Strategi Pembelajaran Berorientasi KTSP,” Jakarta: PT. Prestasi Pustakarya, 2011, pp. 22-23.

[29] Evans \& N. J. Gibbons, "The interactivity effect in multimedia learning," Computers \& Education, vol. 49, pp. 1147-1160, 2007.

[30] M. E. A. Babiker, "For Effective Use of Multimedia in Education, Teachers Must Develop Their Own Educational Multimedia Applications," Turkish Online Journal of Educational Technology (TOJET), vol. 14, pp. 62-68, 2015.

[31] F. Martin \& Marsha L. Carr, "An Exploratory Study on K-12 Teachers' Use of Technology and Multimedia in the Classroom," Journal of Educational Technology, vol. 12, pp. 7-14, 2015.

[32] J. S. Keengwe \& Hussein, "Using computer-assisted instruction to enhance achievement of English language learners," Education \& Information Technologies Journal, vol. 19, pp. 295-306, 2014. 